\title{
Young people and the Great Recession: Variations in the school-to-work transition in Europe and the United States
}

\author{
Ingrid Schoon,i.schoon@ucl.ac.uk \\ JohnBynner,j.bynner@ucl.ac.uk \\ UCL Institute of Education, UK
}

\begin{abstract}
This paper reviews evidence on young people in Europe and the US making the transition from school-to-work before and after the 2008 Great Recession. Taking a macro-level perspective, similarities and differences in education and employment experiences across different European countries are described, considering the role of different institutional support systems in 'scaffolding' young people's transitions to independence. It is argued that the 2008 financial crisis brought with it reduced employment opportunities for young people and accelerated pre-existing trends towards prolonged education participation and precarious employment. There are, however, considerable variations across different countries, highlighting the role of social institutions in supporting young people during the school-to-work transition. Transition systems that created bridges between education and employment are associated with lower national levels of youth unemployment, while young people coming of age in less-protective transition regimes suffered highest levels of youth unemployment, high levels of temporary employment and not being in education, employment or training (NEET).
\end{abstract}

Key words Young people $\bullet$ school-to-work transitions $\bullet$ the Great Recession $\bullet$ transition regimes $\bullet$ comparative research

To cite this article: Schoon, I. and Bynner, J. (2019) Young people and the Great Recession: Variations in the school-to-work transition in Europe and the United States, Longitudinal and Life Course Studies, vol 10 no 2, 153-173, DOI: $10.1332 / 175795919 X 15514456677349$

\section{Introduction}

In the aftermath of the 2008 Great Recession (GR), the global financial crisis which devastated the world economy, employment opportunities for young people aged 16 to 24 years declined dramatically (Bell and Blanchflower, 2011; Schoon and Bynner, 2017). Although the GR ended officially in June 2009, its impact is still affecting the lives of many. In 2017 the global youth unemployment rate was 13.1\% - the same 
as at the peak of the crisis in 2011 and 2013, despite a slight recovery between 2014 and 2016 (ILO, 2017). Many young people continue to struggle to find quality jobs. For example, in the European Union (EU) almost one third of young people are considered at risk of poverty or social exclusion, facing long-term unemployment, or involuntary temporary or part-time work (European Commission, 2016). A problematic entry into the labour market may not just be a temporary experience, but may bring with it longer-term consequences regarding deteriorating employment prospects, also described as 'scarring' (Arulampalam, 2001) or 'signalling' effects to employers (Eurofound, 2017).

There are, however, considerable variations regarding the impact of the GR on education and employment transitions across countries (Bell and Blanchflower, 2011; Danzinger, 2013; Sironi, 2018), pointing to the crucial role of institutional leverage in buffering recession effects. Countries differ regarding demographic trends (the size of the youth population), economic conditions, labour market structures and the way in which institutions regulate access to education, training, employment and welfare support. To gain a better understanding of the impact of the recession on youth transitions it is thus necessary to consider a sample of diverse national experiences to detect common and diverging trends.

Guided by a life-course approach (Elder, 1999; Heinz, 1999, 2009; Elder et al, 2015; Shanahan et al, 2016; Schoon and Bynner, 2017), we take into account the characteristics of institutional structures and associated transition systems in shaping experiences of young people making the school-to-work transition (SWT). Transition systems can be defined as the relatively enduring feature of national institutional and structural arrangements, including aspects of the education and training system, the labour market, the welfare system, family structures and other institutions that shape transition processes and outcomes (Raffe, 2008, 2014). Here we draw in particular on Walther's (2006) typology of SWT regimes, differentiating between sub-protective, universalistic, liberal and employment-centred transition regimes. We argue that variations in institutional structures for managing the SWT play a crucial role in shaping transition experiences and buffering the effects of a sudden economic downturn.

Adopting a macro-level perspective, we describe how processes of the SWT differ between countries, focusing on experiences in education and employment transitions before and after the GR across different European countries and the US. This paper sets the scene for the Special Issue, describing past and present labour market trends using macroeconomic data from the Organisation for Economic Co-operation and Development (OECD). We address the question whether the 2008 financial crisis transformed or merely reinforced, and in some cases accelerated, pre-existing trends (stretching back to the 1970s) towards prolonged and more precarious youth transition and ask what is the role of institutional factors across different countries in buffering young people against recession effects.

The choice of countries is motivated by their shared status as developed economies with distinctive features regarding structures of their SWT transition systems at the time when the recession struck. We contrast the 'neo-liberal' deregulatory framework of the US and Britain with the employment-focused 'dual system' of Germany and Austria, the 'universalistic' Nordic model prevalent in Finland and Sweden, and the 'sub-protective' transition system which applies to southern European countries such as Spain, Portugal and Greece. 


\section{School-to-work transitions in times of socio-economic change}

The SWT generally spans the phase between completion of full-time education or training, the entry into paid employment, and establishing oneself in a labour market career. It is a key developmental task for young people, a make-or-break period, in which young people try to balance pressures for completing higher levels of educational qualifications and establishing themselves in the labour market, as well as other social role transitions, such as moving away from the parental home and starting a family. Within life-course theory the SWT process can be conceptualised as a status passage in the institutionalised life course (see, for example, Shanahan, 2000), which is guided by country-specific age-related legal norms such as minimum school leaving age or working-hours restrictions. The SWT can be understood as an institutionalised sequence of status-role transitions (transition from education to employment) and role configurations (working and studying at the same time) based on social norms regarding age-appropriate behaviour, timing and sequencing of status/ roles (Settersten, 2007). The state channels SWT patterns through related policies and welfare institutions, that facilitate normative transitions, such as entry into paid employment after leaving full-time education, and buffer against non-normative discontinuities in the life course, such as spells of unemployment (Heckhausen and Buchmann, 2018). These social structures are mediated by young people and their parents' informal expectations regarding appropriate ages for the completion of education or entry into continuous paid work. Such expectations can vary by cultural context, gender, ethnicity and social class, and are highly responsive to economic and social change (Neugarten, 1996; Liefbroer and Billari, 2010; Buchmann and Kriesi, 2011). For example, external shocks, such as an economic downturn, have the potential to create diverging destinies, to transform or to accelerate existing trends (Schoon and Bynner, 2017).

Generally, across Western societies, the SWT has become more prolonged as young people are increasingly required to complete higher levels of education to compete in a changing labour market (Shanahan, 2000; Blossfeld et al, 2005; Furlong, 2010; Ashton and Bynner 2011; Settersten et al, 2015). Following the introduction of new technologies, the decline of (unskilled) manual jobs and the gradual shift towards automation (Furlong, 2010; Ashton, 2017), the transition into paid employment has been delayed for increasing numbers of young people, often until their mid- or late twenties, or even early thirties. Higher education is no longer a luxury, but becoming a necessity for those who want a job with decent pay and good prospects.

There has been an expansion of the number of young people entering higher education, including those from less privileged backgrounds (Blossfeld et al, 2005). Yet, although the current student population in higher education represents a more diverse group than 40-50 years ago, there are persisting concerns about equality of access and completion rates depending on the individual's cultural and socioeconomic background (Breen, 2010; Pfeffer and Hertel, 2015). Nonetheless, it has been argued that since the 1970s individual behaviour regarding education and career transitions has become less bound by traditional norms and values, that the sources of socialisation and collective identity associated with class, gender and ethnicity and workplace solidarity - and, in consequence, the exercise of agency through, for example, aspirations and job search - has become more diverse and individualised (Giddens, 1991; Beck, 1992). 
The assumption of increasing individualisation conceptualises the life course, including the SWT as a deliberative project, a 'reflexive' or self-steered process, governed by risks that have to be circumvented. That is to say the SWT is understood as something you must largely accomplish yourself (Beck, 1992), as a 'project' that individuals themselves construct, as an expression of their individual agency. The assertion that individuals are now free to choose their destination has, however, been questioned, as there is persisting evidence of unequal access to educational and career opportunities (Bynner, 2001; Furlong and Cartmel, 2007; Schoon, 2007; Antonucci et al, 2014; Schoon and Lyons-Amos, 2016, 2017). Moreover, there are country-specific variations in the available routes through education and into the labour market, pointing to the role of institutions and social structures in guiding the SWT that we discuss later. First, we describe trends and variations in key markers of the SWT, that is, experiences regarding education and employment transitions before and after the GR. Considering the GR as a major shock, we would expect a considerable transformation of transition experiences before and after its occurrence.

\section{Education participation}

Figure 1 shows the education enrolment rates for young people aged 20 to 29 over the period 2005-15 in different OECD countries. Enrolment rates are expressed as net figures calculated by dividing the number of students of a particular age group enrolled in all levels of education by the size of the population of that age group. Generally, figures are based on head counts and do not distinguish between full-time and part-time study. In some OECD countries, part-time education is only partially covered in the reported data.

The available OECD data suggest that between 2005 and 2010 there was only a slight (if any) increase in enrolment in Germany, Switzerland and the US. For most other countries there was no comparable trend data available, or there was no change, while in Portugal we see a considerable increase since 2013. Moreover, with the exception of Sweden and Norway, where from a high start there was a small decline in staying on in post-compulsory education across the period, for most others (such as the Netherlands) there was either a small rise or a broad flattening out of the rates. We thus see the increasing tendency to stay on in education as the economy transformed but only modest additional effects in response to the recession itself. Evidence from studies using longitudinal panel data likewise suggests that levels of participation in full-time education among 16- to 25-year-olds across Europe and the US persisted during and after the recession and increased only slightly (Crosnoe and Smith, 2017; Lyons-Amos and Schoon, 2017; see also Sironi, 2018).

\section{Educational achievement}

Figure 2 moves the focus to educational achievement in successive age groups. A set of 12 bar diagrams show the trends in educational attainment among 25- to 34-yearolds between 2000 and 2016 across different countries (OECD, 2017). The data are taken from OECD and Eurostat databases, which are compiled from National Labour Force Surveys by the OECD LSO (Labour Market, Economic and Social Outcomes of Learning) Network. Educational attainment is measured as the percentage of the 
Figure 1: Enrolment in education (20- to 29-year-olds) percentage in same age group, 2005-15

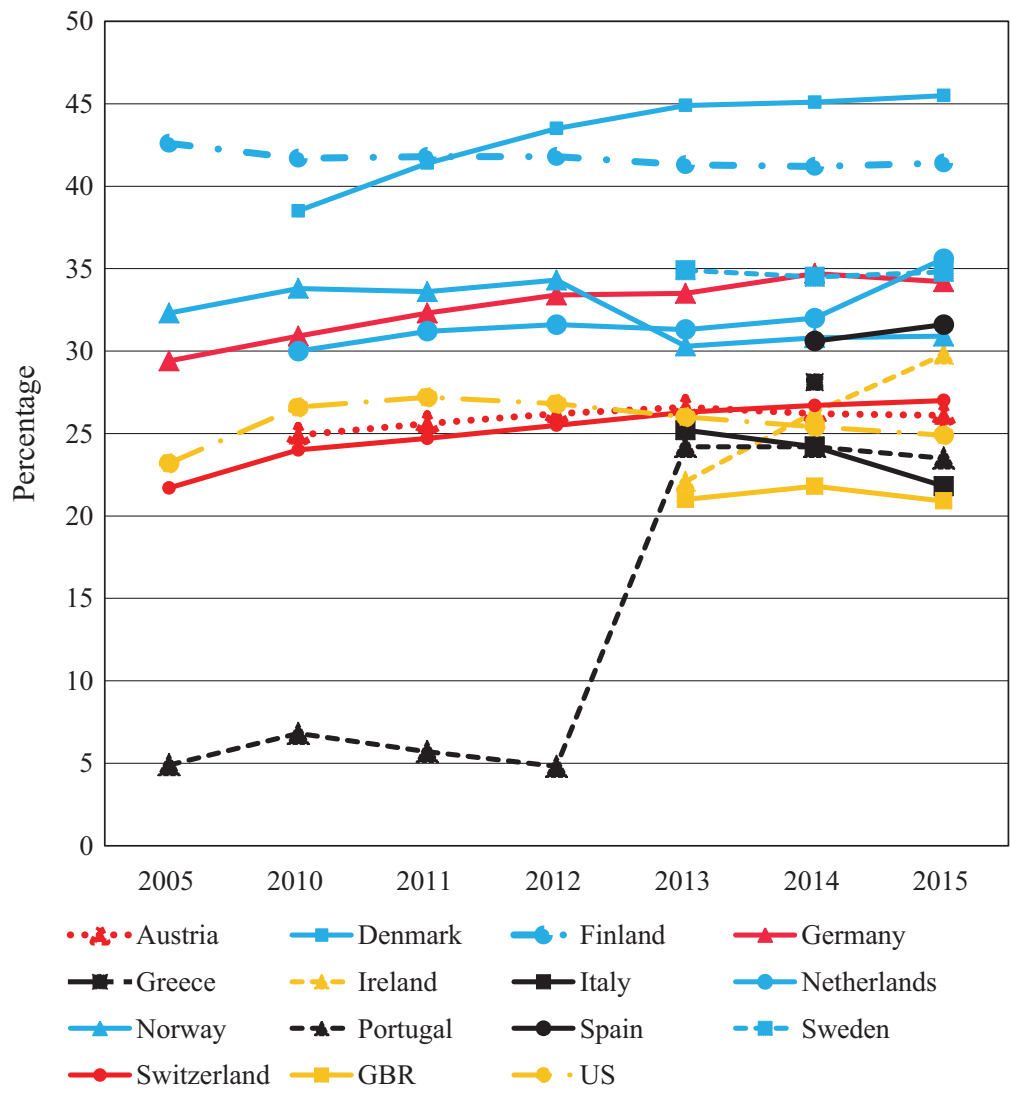

Source: OECD (2018a), as at 16 April 2018.

population for each country that has achieved a certain level of education and holds a formal qualification at that level, grouped into the three categories: 'below statutory', 'upper secondary' and 'tertiary'.

The OECD definition of a tertiary qualification includes theoretical programmes leading to advanced research and high-skill professions such as medicine. Upper secondary education typically follows completion of the lower secondary schooling that qualifies the recipient for tertiary education. Lower secondary education certifies achievement of recognised educational standards, of which the basic skills of literacy and numeracy and IT competence are central.

Generally, across Europe and the US, the share of 25-34 year-olds with a tertiary qualification has increased, especially after 2010, while the share of those with below secondary-level qualifications has decreased (OECD, 2017). Figure 2 shows that the largest increases in the share of tertiary education qualifications since 2010 (over 8\%) are observed in Switzerland, Greece and Portugal, suggesting that since the 2008 GR the trend towards extended education participation and achievement in these countries has accelerated. In the other countries, however, major education expansions had already occurred before then. Figure 2 also shows considerable variations across countries, with the UK and Ireland having the highest share of tertiary graduates (over 50\%), while Germany, Austria and Portugal have the lowest share (at or below 40\%). 
Figure 2: Trends in educational attainment of 25- to 34-year-olds in selected countries
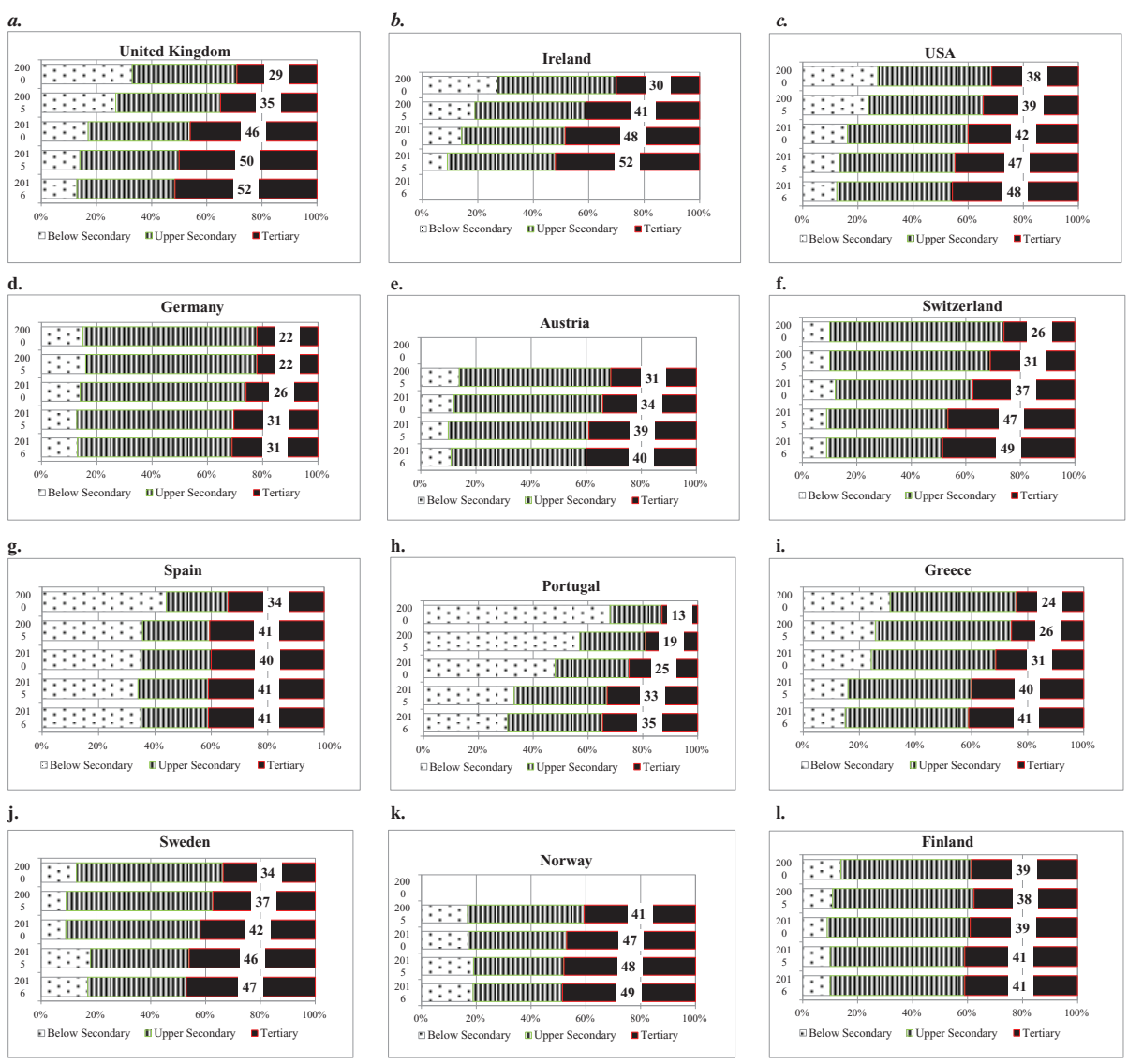

Source: OECD (2017).

Education is generally identified as the best protection against the experience of unemployment, and in most countries prolonged education participation has acted as a buffer, softening the impact of a downward trend in available employment opportunities, even if this meant that some young people are being 'warehoused' in educational institutions during a period of reduced employment opportunities (Schoon and Bynner, 2017). Figure 2 suggests a degree of discontinuity in educational attainment, with an increasing spurt in most countries from 2010 to 2015 onwards, that is, in the aftermath of the GR. Yet, on aggregate well over half the youth population did not achieve the standard of a tertiary degree, which might also reflect high levels of drop-out, which are especially high in the US. The data thus suggest the need for viable alternative pathways for establishing oneself in the labour market, in addition to and above the academic track (Schoon, 2015).

\section{Entry into employment before and after the recession}

Employment opportunities in most Western countries have changed considerably since the 1970s, following the introduction of new technologies, the decline in manual jobs especially in manufacturing, and the increasing participation of women 
in higher education and in the labour force (Banks et al, 1992; Evans and Heinz, 1994; Müller and Gangl, 2003; Blossfeld et al, 2005; Schoon and Silbereisen, 2009; Ashton, 2017). Furthermore, in most developed countries, fuelled by technological transformation and the collapse of traditional manufacturing and heavy industry employment such as coalmining, there has been a growth of white collar, high tech and service jobs accompanied by a 'deskilling' of many of those employed in what had been until then skilled occupations (Ashton, 2017). Moreover, in the aftermath of the GR austerity measures were introduced, including labour market reforms to promote flexible employment, cuts in state support for students, and in some countries charging tuition fees for higher education (Antonucci et al, 2014). In addition, youth joblessness had been a major concern in many OECD countries, even before the GR (Blossfeld et al, 2005; Bell and Blanchflower, 2011). Youth unemployment rates are generally more sensitive to business cycles than adult unemployment (OECD, 2010) and at times of recession young people have most difficulty in finding employment and holding on to it. Figure 3 shows the aggregated

Figure 3: Trends in the youth unemployment rate (age 16 to 24). Total, percentage of youth labour force, 2000-17.

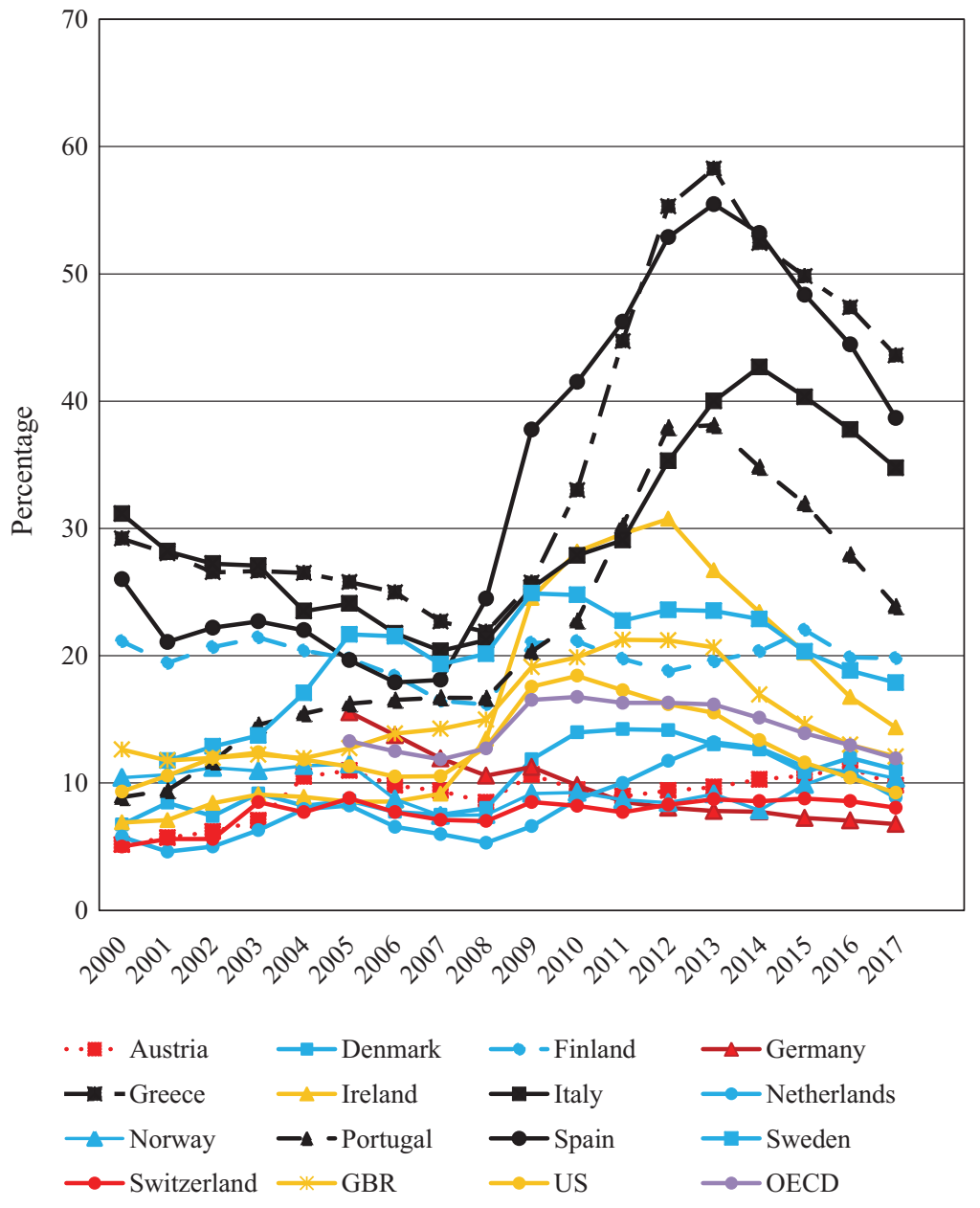


national time series data of trends in youth unemployment rates between 2000 and 2017 across different countries.

In some countries, such as Greece and Spain, youth unemployment was already relatively high, even before the onset of the GR, with, as the figures show, dramatic increases to over 50\% in its aftermath, especially during peak periods in 2012/13. Most countries witnessed an increase in youth employment after 2008, following a slight decline between 2004 and 2007 (see also ILO, 2012). Notably, in Ireland youth unemployment increased from 9\% in 2007 to 30\% in 2013, followed by a subsequent recovery to pre-recession levels. Moreover, for some countries there had been only relatively small increases (Switzerland, Austria, Denmark and Norway). Finland also saw relative stability in youth unemployment rates, although fluctuating around relatively high levels of about $20 \%$. The US witnessed a sharp increase, rising from about $10 \%$ in 2006 to over $18 \%$ in 2010 with a subsequent recovery to pre-recession levels. Sweden saw a rise from around $12 \%$ in 2001 to over $20 \%$ in the aftermath of the GR, staying at that level until 2016. Germany and Switzerland are the only countries that actually witnessed a decline in youth unemployment in the aftermath of the GR, although in the case of Germany from relative high pre-recession levels (around 15\%) in 2005.

The data suggest long-term and time-lagged effects of the economic downturn on employment opportunities. Even ten years after the onset of the GR youth unemployment in some countries (in particular Spain, Italy and Greece) had not returned to pre-recession levels. Even more worrying, the numbers of young people disconnected from education and employment continues to rise.

\section{Not in education, employment or training (NEET)}

Unemployment rates are a key indicator of the state of a nation's economy, the consequences of which are crucial for shaping labour market opportunities. Unemployment rates do however not include students, or those who are identified as economically inactive. The term 'not in education employment or training' (NEET), has been widely used in recent years to identify existing or potential transition problems including unemployment as well as labour market inactivity. It is, however, a rather broad category, masking considerable heterogeneity. Various factors contribute to young people being inactive and not seeking employment. Among young women, the main reason for labour market inactivity is childcare responsibilities, while health and other factors are more prevalent among young men (OECD, 2017). In addition, the NEET category includes those who opt out temporarily through 'gap years' and travelling before engaging fully with a professional career - often involving further qualifications among university graduates (particularly common in the EU). This in turn weakens the overall association of NEET with social disadvantage. NEET can, however, also include those who have fallen out of the benefit system - those who are on the street, the homeless and so on - which makes it a complex indicator.

Moreover, there are distinct cross-national differences in identifying NEET. For example, reflecting the relatively compressed SWT in the UK compared with other countries, the age limits for NEET were set originally at 16-19. This was before the compulsory requirement from 2015 that young people stay engaged in some form of education up to age 18. For our comparative purposes it makes good sense to adopt the OECD definition (shared with the EU) of ages 18 to 24, reflecting a continuing 
period of postponed independence. Here we focus on young people aged 20 to 24 , reflecting a critical period in their lives following completion of compulsory education (which varies between ages 14 and 18 in Europe) when important decisions regarding continuing in higher education or entering paid labour have to be made.

Figure 4 shows the percentage of young people (aged 20 to 24) experiencing NEET over the period 2000 to 2017 . The OECD average NEET rate is quite stable over time, affecting around one in six of all young people aged 20 to 24 between 2000 and 2017. Italy and Greece showed generally higher levels, in particular directly after the 2008 crisis, and Spain and Ireland experienced a dramatic increase in the aftermath of the GR. For example, in Spain the level of NEET increased from 17\% in 2005 to over $30 \%$ in 2012, and in Ireland from $12 \%$ to $26 \%$. The US and the UK show similar

Figure 4: Youth (age 20-24) not in employment, education or training (NEET). Trends 2000-17.

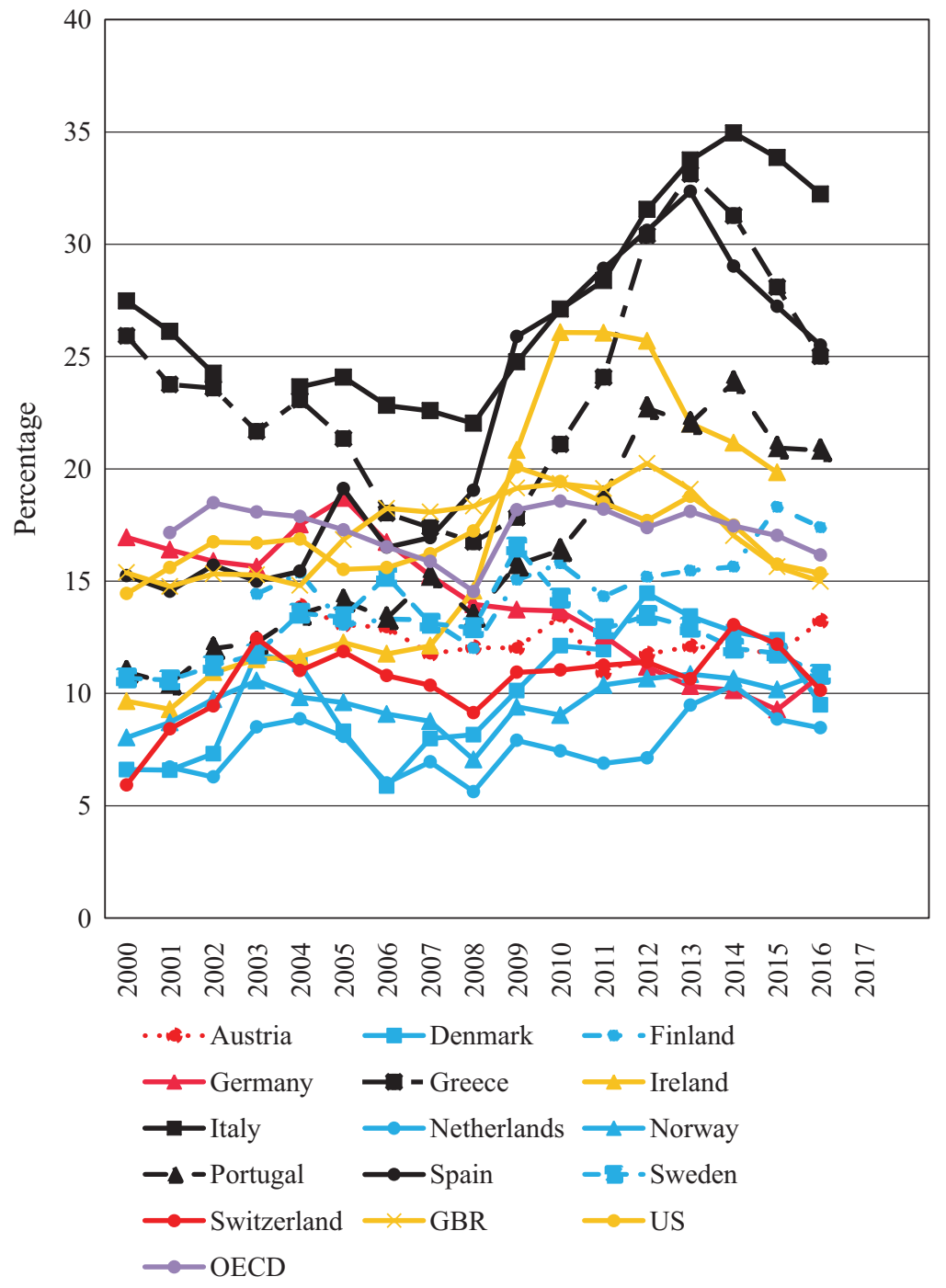

Source: OECD (2018b). 
NEET levels to the OECD average, whereas the Netherlands, Denmark, Norway, Germany, Austria and Switzerland showed lower levels following the economic crisis. However, while in the Netherlands the percentage of young people classified as NEET remained at a low level (below 10\%), Germany started at a higher level of about $15 \%$, reflecting the OECD average at the time, with falling NEET rates in the aftermath of the GR. Thus, there were considerable national variations in the extent to which young people were affected by the GR, likely to be associated with different 'institutional filters' (Blossfeld et al, 2005), specific cultural contexts, as well as regulations regarding education, training and employment opportunities, which we will discuss in the next section.

In interpreting the findings, we need to keep in mind that the subgroup of young people identified as NEET is very heterogeneous, comprising those who are unemployed looking for work, as well as those who are inactive (due to childcare responsibilities, ill health, social exclusion or other factors such as being on a 'gap year'). This reflects in many respects the transition processes that young people are going through, rather than a category in which to locate them. For example, based on data from the 2013 European Labour Force Survey, about a third of young people classified as NEET are only temporarily inactive and may soon re-enter employment, education or training (Eurofound, 2016). Generally, the largest proportion of young people categorised as NEET across Europe are those with an upper secondary level of education (Eurofound, 2016). Nonetheless, in 2013, on aggregate 22\% of young adults experienced long-term unemployment and about 6\% became discouraged (in particular in Mediterranean countries), in that they stopped looking for work or further training because they believed that there were no job opportunities for them (Eurofound, 2016). Those who are economically inactive will, however, need some kind of financial support, typically provided from parents, although this will vary according to the wealth of parents. Moreover, in circumstances where young adults cannot draw on their parents for support, as is the case with care leavers, those who have no longer any contact with their parents, or those who have fallen out of the benefit system, there need to be alternative support structures.

Despite its limitations, the NEET indicator can be a useful tool in enhancing understanding of young people's vulnerabilities in terms of labour market participation and social inclusion, in particular if the differentiation of different subgroups is clearly indicated. Central to the issue of youth unemployment and detachment from the labour market are the potential long-term damaging effects, described as 'scarring' effects (Arulampalam, 2001), or as sending a negative 'signal' to prospective employers undermining prospects of secure employment in the mainstream economy (Eurofound, 2017) with the potential irrevocable risk of permanent social exclusion to follow (Maguire, 2015; Blossfeld, 2017; Groh-Samberg and Wise, 2017). Some of the young people classified as having NEET status may thus be moving along a 'trajectory of disadvantage' (Bynner and Parsons 2002) that the GR reinforced.

\section{Insecure employment}

In the context of restricted labour market opportunities another key feature merits attention: the growing proportion of employees with fixed-term, temporary and zero-hour contracts and a shift towards more precarious employment arrangements and low pay, even among graduates (Standing, 2011; Ashton, 2017; Bloodworth, 
2018). This trend partly arises from increased outsourcing of jobs such as cleaning and care work to private agencies, and partly from labour market reforms introduced in the aftermath of the recession, promoting 'flexible' employment (Antonucci et al, 2014). Young people have been hit particularly hard by these changes, as temporary employment among the young (that is, 16- to 24-year-olds) is significantly higher than among the workforce overall (Eurostat, 2017b) and young people now make up the core of what Standing (2011) calls the new 'precariat'. The recession accelerated this trend towards precarious employment. A particularly striking feature of precarious and potentially exploitative employment is its growing presence in all countries (Standing, 2011; Eurofound, 2013; Prassl, 2018).

Figure 5 shows trends in the proportion of young people aged 15 to 24 years in temporary employment between 2004 and 2012 in different European countries. According to Eurostat (2017b), temporary employment includes work under a fixedterm contract, as against permanent work where there is no end-date. It includes

Figure 5: Proportion of 15-24 year olds in temporary jobs, 2004-12.

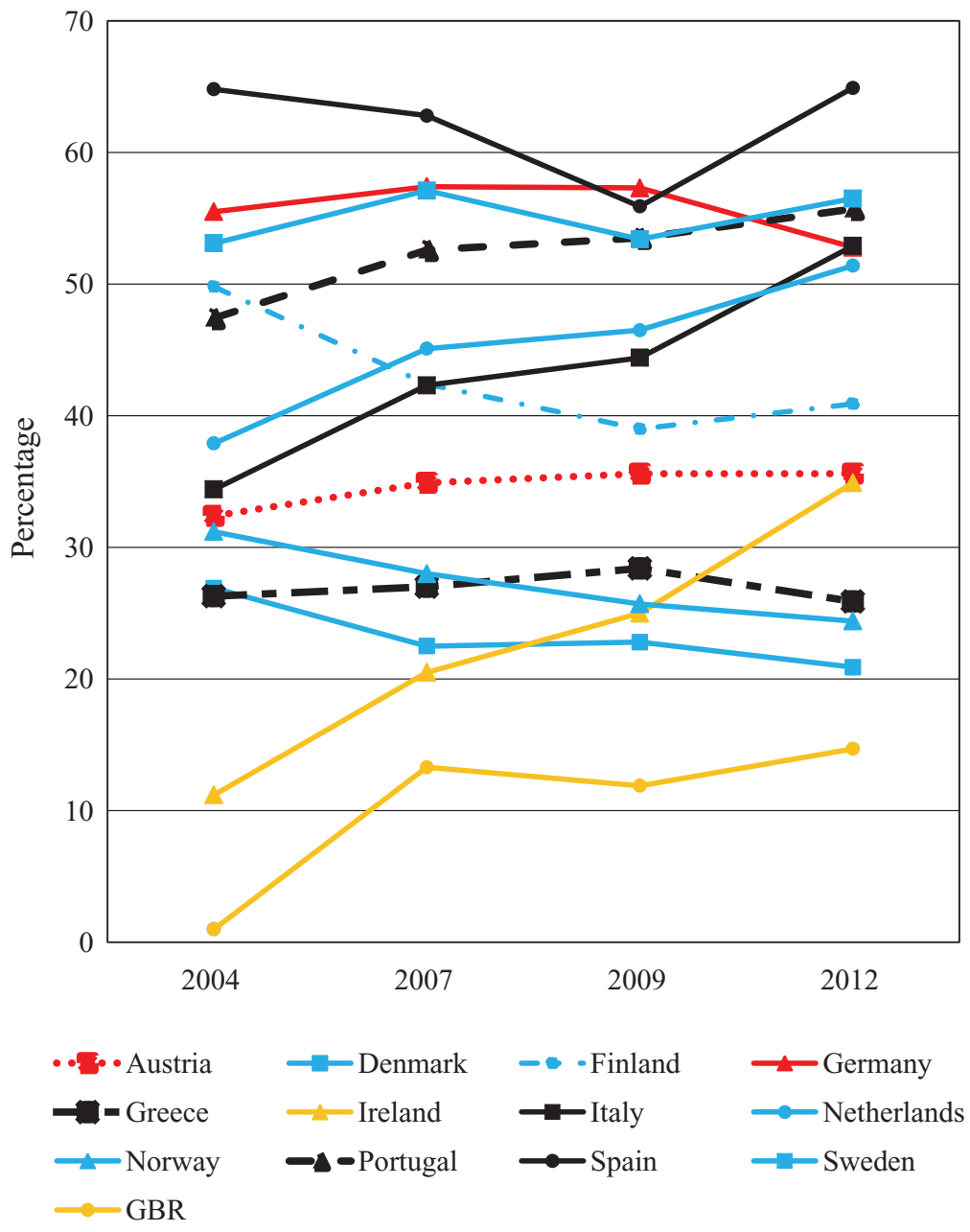


people in seasonal employment; those who were engaged first by an agency or employment exchange and then hired to a third party to do a specific task (unless there is a written work contract of unlimited employment duration); people with specific training contracts; and those who are in temporary employment as part of vocational education and training.

Across most European countries the employment rate for young people with temporary work contracts increased in the aftermath of the recession (Eurofound, 2013). Similar trends can be observed for the slightly older 25 to 29 years age group, although the number is only about half the proportion of 15- to 24-yearolds employed on temporary contracts (Eurofound, 2013). Levels of temporary employment are particularly high in Spain, Sweden and Germany, with over 50\% of 15- to 24-year-olds already being on temporary contracts in 2004 and relatively small increases in the aftermath of the GR. The increase in temporary employment was particularly marked in Italy, Ireland and the Netherlands. In Italy temporary employment rose from 34\% in 2004 to $53 \%$ in 2012; in the Netherlands from 38\% to $51 \%$; and in Ireland from $11 \%$ to $35 \%$. Some countries, however, witnessed a decrease of temporary employment: in Denmark temporary employment fell from $27 \%$ in 2004 to $21 \%$ in 2012; in Norway from 31\% to 24\%; and in Finland from $50 \%$ to $41 \%$. The lowest levels of temporary employment were found in the UK, increasing from $11 \%$ in 2004 to $15 \%$ in 2012 .

Eurofound (2013) also assessed the reasons why 15- to 24-year-olds were in temporary employment. In Germany, Austria and Denmark, the major reason was vocational education and training involving fixed-term contracts. In these countries the classification of temporary employment includes young people in vocational education and training, and the incidence of temporary working among those aged 25 and over is much lower than for those younger than 25. In Spain, Portugal and Greece, the majority of young people are in involuntary temporary employment, in Greece often as family workers. In the UK, in addition to involuntary temporary employment, a considerable number of young people (36\%) in temporary employment say that they actually choose casual work.

\section{The role of institutional structures in contemporary youth research: transition regimes}

Countries differ regarding the institutional structures guiding the transition from school to work. Comparative research on youth transitions among European countries has focused in particular on labour market regulation, and the nature of the linkage between educational systems and the labour market (Breen and Buchmann, 2002; Buchmann and Kriesi, 2011). These institutional factors are assumed to influence and channel transition behaviours by offering a diverse set of opportunities and constraints (Heckhausen and Buchmann, 2018), reflecting features of their different transition regimes (Walther, 2006; Raffe, 2014).

As already mentioned, Walther (2006) differentiates between sub-protective, universalistic, liberal and employment-centred transition regimes. This differentiation has been highly influential in European comparative youth research, although more recent approaches have advanced a 'welfare mix' approach, to clarify the different contributions made by the state, the family and the labour market in shaping youth transitions (Antonucci et al, 2014). 
The sub-protective transition regime model (colour coded black in Figures 1, 3-5) applies primarily to southern European countries, such as Spain, Portugal and Greece. Education is mostly comprehensive, although the rate of early school leaving with below upper secondary qualifications is high (see Figure 2). For example, until recently the majority of young people in Portugal left education with below secondary-school-level qualifications. Vocational training is not well developed, nor highly valued, is mainly provided by professional schools and the involvement of companies is low. The labour market is characterised by informal or insecure employment and limited social protection. Due to the economic weakness of many regions, there are high rates of youth unemployment (see Figure 3), prolonged periods of job search and a long waiting phase during which young people depend primarily on their families for support.

Universalistic transition regimes (colour coded blue in Figures 1, 3-5) prevalent in Scandinavian countries such as Sweden, Norway and Finland are characterised by a comprehensive school system. National frameworks set standards, with routes provided for general and vocational education in which school-managed work experience with local firms plays an increasing part. Notably, in Sweden 'free schools', outside state control, were introduced by a conservative government in the 1990s, and are becoming increasingly popular. Indeed about a fifth of all schools in Sweden are now 'free schools'. More generally, universalistic transition systems are flexible enough to allow for individual learning and training plans. Information, guidance and counselling are widely institutionalised at all stages of education, and the transition to employment is facilitated by identifying individual motivation and supporting personal development. Employment opportunities are typified by an extended public sector and a strong emphasis on equal opportunities. Young people have the right to social assistance from 18 years onward, regardless of the socio-economic status of their families. If they are participating in either formal education or post-school training they receive an educational allowance. The welfare system is embedded in the principles of collective social responsibility in which young people's potential is considered as a vital resource for the future of society.

The 'liberal' transition regime model (colour coded amber in Figures 1, 3-5), predominant in Anglophone countries, such as the UK, the US and, to an extent, also in the Republic of Ireland, values individual rights and responsibilities more than collective provision. Education is mostly comprehensive, but the structures in which it operates are quite different. For example, there is selection in Ireland and in some English local authorities. The labour market is also largely deregulated with a large segment of low-skilled and non-standard jobs. Most liberal transition systems provide no structured path into skilled employment without college, strongly emphasising college education as a prerequisite for a viable career. For young people not planning to go to university the further education colleges in Ireland and England, and community colleges in the US provide the main post-compulsory education route for gaining vocational qualifications or making good on previous poor school performance. But more generally, young people and parents do not regard a vocational training pathway as a promising option. Against this background and in response to skill shortages, the UK is currently aiming to promote apprenticeships and technical training courses. On the other hand, the neo-liberal austerity approach to public funding following the GR led to cuts in further education and community college provision and major increases in university tuition fees. Levels of benefits 
(when young adults are eligible for them) are low and limited in time. They are also conditional on active job search.

Employment-centred transition regimes (colour coded red in Figures 1, 3-5) are typical for Germany (and most German-speaking countries, that is, Austria and Switzerland) as well as to a limited extent in France and the Netherlands. Education is organised selectively, allocating young people to occupational careers and associated social position at an early age. For example, in Germany young people are already channelled by age ten into different tracks leading to the skilled trades, white collar intermediate occupations requiring apprenticeships, and professional careers requiring university degrees. Vocational training plays a central role and is relatively standardised with five major pathways: (1) vocational education and training (VET), that is, apprenticeship under a training contract or full-time vocational school, (2) pre-vocational training ('transition system') for those who do not succeed in getting an apprenticeship, (3) dual studies (combining VET and college), (4) university of applied sciences and (5) research university. Enrolment to dual studies and universities has been growing in the past decade, as a response to the employment uncertainty created by the GR. Germany has been building its 'dual system' of apprenticeship (work-based training in a company coupled with one of two days per week in a vocational school) for more than a century. And through the commitment of the social partners (employers, unions and local government members), who govern and monitor the system at local level, the country has maintained its institutional importance across changes of government.

Despite its advantages, employment opportunities in employment-centred countries can be polarised (Rueda, 2014). For example, in Germany there is a differentiation between a secure core, the so-called 'insider' section of the workforce in secure employment with a generous social security provision, and the periphery, the 'outsider' section of the workforce with access to mainly temporary or precarious employment and residual benefits (Emmenegger et al, 2012).

\section{Where did young people fare best in the aftermath of the recession?}

A central purpose in the specification of 'transition systems' is to identify features of successful systems that enable a smooth integration into the labour market (Raffe, 2008). In the typology described above, the focus of each of the four identified types lies in the differences and similarities in structures of education and training, cultural assumptions and expectations, and the link between education systems and the labour market (Walther, 2006). Generally, the labour market integration of new entrants tends to be faster in countries characterised by strong institutional linkages between education and the labour market, and strong institutional networks which can support the SWT (Brzinsky-Fay and Solga, 2016; Schoon and Bynner, 2017). In contrast, young people coming of age in countries with a sub-protective transition regime (such as in Spain, Greece and Portugal) have clearly been hit hardest by the recession, suffering the highest levels of youth unemployment, and high levels of temporary employment as well as NEET. The comparatively low rate of youth unemployment and NEET in Portugal can be explained by a large number of young people emigrating to other countries, reducing labour force participation and contributing to lower levels of youth unemployment (Dolado, 2015). Employment opportunities for 
young people in countries with a liberal or a universalistic transition regime were less strongly affected, yet at the height of the recession unemployment reached high levels, in particular in Ireland, where unemployment rates reached over 30\%. Finland and Sweden, representatives of a universalistic transition regime, also suffered high youth unemployment while the Netherlands and Denmark rates were largely unaffected.

The relative success of employment-focused countries, such as Austria, Germany and Switzerland in keeping young people engaged in the labour market can be explained by the efficient use of vocational training programmes and strong linkages between education and the labour market, as well as efforts to establish bridges between vocational training and formal degrees, such as the dual studies scheme in Germany, opening pathways to higher education. Yet, focusing on the impact of the vocational training system can mask other factors, such as good economic conditions, as reflected in the strong association between national youth unemployment rates and the unemployment rates of prime age workers (aged 25-54) in Germany, for example (Brzinsky-Fay and Solga, 2016). Nor does it take into account the relative role of several distinct institutional characteristics, such as employment protection legislation or product market regulation, or the shortage of high-quality secure jobs which some critics point out is the price of maintaining full employment (Barbieri et al, 2018). For example, it has been argued that the apparent success of employment-focused countries, such as Germany, in staving off, with the help of legislation, unemployment during and after the GR, was bought at the price of job protection for the 'insider' section of the workforce, those with permanent employment contracts (Blossfeld, 2017; GrohSamberg and Wise, 2017). At the same time the 'outsider' section (those combining spells of unemployment with temporary and often part-time work), constitute a nascent precariat - large numbers of the poorly qualified, often comprising minority groups and immigrants. In general, such individuals tend to leave education at the minimum age, usually without any or only low-level qualifications and then, subsequently, spend a significant proportion of their time occupationally inactive.

The differentiation between insiders and outsiders in the labour market is considered to play an important role regarding variations in the distributive implications of social policy (Rueda, 2014). Generally, over the past three decades, there has been an increasing 'polarisation' of the labour market across many OECD countries, a structural segmentation where levels of social and employment protection for labour market insiders are maintained, reducing their vulnerability to unemployment, while support for an increasing number of outsiders is reduced (Ferragina and SeeleibKaiser, 2011; Rueda, 2014). This increasing polarisation seems likely to constitute the major challenge for youth policy and the transition systems of the future. That is to say the generosity of the welfare state, rather than mitigating labour market problems for young people, can become under certain economic conditions, such as the GR, a source of its division.

\section{Limitations of a typological approach for comparative youth research}

The typology of transition regimes described above implies a generalisation in terms of ideal types, the abstractions that enable classification in the case of countries differentiated by relative stable shared or common characteristics (Raffe, 2008). In Walther's (2006) typology the focus lies on differences in structures of education 
and training, the link between educational systems and the labour market, and the role of welfare state policies such as support for participation in education/training and regarding labour market entry. However, differences between countries of the same regime type are not sufficiently specified. For example, the typological approach overlooks within-country differences in institutional structures such as the use of comprehensive secondary education schooling, free schools or variations in stratification. It also does not appropriately account for 'welfare mixes', the different contributions made by the state, the family and the labour market to support young people's SWT (Antonucci et al, 2014). Moreover, the typology does not capture the heterogeneity of employment in terms of job security, working conditions, polarisation and the frequent precarity of youth employment in particular. It also does not address the dynamics of SWTs regarding frequency of job changes, spells of unemployment and inactivity, or the reversal and possibility for transference between education and employment transitions. In addition, the typology is limited to the Western world, not including Asian or African countries, or those from European (post-Soviet) 'transformation societies'.

Future conceptualisations of institutional structures in place to support the SWT should take into account within-country differences regarding education systems (degree of standardisation, stratification and institutional linkages), adopt a more dynamic approach and include indicators of changing youth policies, labour market structures (the levels of regulation, flexibility and precarity), as well as the broader economic environment. In addition, there is need for a more global perspective, moving beyond a focus on the Western world.

\section{Conclusion}

This article has reviewed evidence from aggregate macro-level trend data on the effects of the GR on young people making the SWT across a number of countries in Western Europe and the US. The advantages of aggregate data are that they highlight differences and similarities in the macroeconomic trends between countries, supplying pointers to how the recession was experienced and the policies employed to mitigate adverse changes. This benefit is, of course, at the expense of being able to assess the individual variations through which the GR effects on the SWTS were manifested. The trend data drawn on are longitudinal but only at the national level, in which the unit of analysis is the nation state. Hence it needs to be acknowledged that understanding the GR's effect on individual lives has to be inferred rather than demonstrated from the data presented. The findings thus have to be considered under this caveat.

The data suggest that the GR did not bring about a radical transformation of transition experiences. It was not an instance of a 'creative destruction' as Joseph Schumpeter (1975 [1942]) would call it; the main effect was to accelerate pre-existing trends towards prolonged, and, in particular, more precarious youth transitions. In the aftermath of the GR, fewer young people left education with below secondary-level qualifications and more gained tertiary qualifications. Yet, most markedly the recession did bring with it reduced employment opportunities and a labour market increasingly characterised by insecure, casualised or zero-hour contract work interspersed with periods of unemployment. Such 'precaritisation' of employment is now confronting growing sections of the youth population. In addition, there is a polarisation of the 
labour market, associated with a lack of social protection for 'outsiders' - those who are unable to find permanent employment.

Adopting a macro perspective in comparing youth transitions across countries and over time illustrates the heterogeneity of SWTs in different socio-cultural and historical contexts. Socio-cultural systems provide the blueprint for social lives and associated transition regimes, which regulate opportunities for education and employment. They bestow laws, rules and regulations that delineate distinct pathways for individuals to follow, and also inform attitudes and beliefs by shaping outlooks for the future (Schoon and Lyons-Amos, 2016; Mortimer et al, 2017; Heckhausen and Buchmann, 2018). The life-course principles considered at the beginning of the paper provide a good basis for considering the processes involved. That is to say, the transition to adulthood is a key 'status passage' in the institutionalised life course, where longitudinal trajectories are constructed through available support structures and institutional channelling (Heckhausen and Buchmann, 2018).

Using a typological approach enables the classification of countries in terms of shared or common characteristics and to gain better insight into how relevant transition regimes can moderate the outcomes of economic disruption. Yet, typologies provide only an idealised classification. We find some support for the relevance of the different transition regimes considered here, although they do not capture fully the complexity, heterogeneity and dynamics of SWTs in a changing socio-historical context.

The data suggest that young people making the SWT in sub-protective transition systems were hardest hit in the aftermath of the GR, in that they experienced the highest rates of youth unemployment, temporary work contracts and NEET. Extended transitions in the absence of institutional financial assistance imply prolonged dependence and reliance on family support. Yet, not all young people are able to call on family support, in particular in the absence of relevant legislation regarding increasing the age limit for parental responsibility, or the depletion of family resources through prolonged exposure to economic instability and austerity. At times when there is exceptional economic strain, the institutions concerned with managing the education and training system of any country become the key agents of social policy concerned with ensuring young people have opportunities to participate and engage in society. In particular, strong bridges between the education system and the labour market play an important role in buffering the negative effect of a recession on employment prospects. Progressive, responsive and inclusive institutions are the means of both mediating and moderating the pressures arising from an economic downturn and associated uncertainty. They are crucial in providing viable career opportunities and employment security, in particular for the most vulnerable in society. Without them the record of failed transitions may lay the foundations of permanent social exclusion. In addition, other factors, such as variations in the national economic situation, demographic characteristics, fiscal and monetary policies might, of course, also play a role.

\section{Acknowledgement}

The study is supported by the Wissenschaftszentrum Berlin (WZB), as well as Grant Numbers ES/J019658/1 and ES/J019135/1 from the British Economic and Social Research Council (ESRC) for the Centre for Learning and Life-chances in the Knowledge Economies (LLAKES, Phase II) and the ESRC workshop series. The content is solely the responsibility of the authors and may not represent the views of the sponsors. 


\section{References}

Antonucci, L., Hamilton, M. and Roberts, S. (eds) (2014) Young people and social policy in Europe: Dealing with risk, inequality and precarity in times of crisis, Basingstoke: Palgrave Macmillan.

Arulampalam, W. (2001) 'Is unemployment really scarring? Effects of unemployment experiences on wages', The Economic Journal, 111(475): F585-F606. doi: 10.1111/1468-0297.00664

Ashton, D. (2017) 'Globalization and its impact on the political, economic, and labor market aspects of the youth transition', in I. Schoon and J. Bynner (eds) Young people's development and the Great Recession: Uncertain transitions and precarious futures, Cambridge: Cambridge University Press, pp 25-51. doi: 10.1017/9781316779507.003

Ashton, D. and Bynner, J. (2011) 'Labour Market, Employment and Skills'. In M. E. J. Wadsworth and J. Bynner (Eds.), A Companion to Life Course Studies. The social and historical context of the British birth cohort studies, London: Routledge.

Banks, M., Bates, I., Breakwell, G., Bynner, J., Emler, N., Jamieson, L. and Roberts, K. (1992) Careers and identities, Buckingham: Open University Press.

Barbieri, P., Cutuli, G. and Passaretta, G. (2018) 'Institutions and the school-to-work transition: Disentangling the role of the macro-institutional context', Socio-Economic Review, 16(1): 161-83. doi: 10.1093/ser/mww019

Beck, U. (1992) Risk society: Towards a new modernity, London: Sage.

Bell, D.N.F. and Blanchflower, D.G. (2011) 'Young people and the Great Recession', Oxford Review of Economic Policy, 27(2): 241-67. doi: 10.1093/oxrep/grr011

Billari, F.C. and Liefbroer,A.C. (2010) 'Towards a new pattern of transition to adulthood?', Advances in Life Course Research, 15(2/3): 59-75. doi: 10.1016/j.alcr.2010.10.003

Bloodworth,J. (2018) Hired: Six months undercover in low-wage Britain, London:Atlantic Books.

Blossfeld, P.N. (2017) 'Labor market entry in Germany before and after the financial crisis: An analysis of duration of labor market entry, quality of first job and fixedterm employment', in I. Schoon and J. Bynner (eds) Young people's development and the Great Recession: Uncertain transitions and precarious futures, Cambridge: Cambridge University Press, pp 208-32.

Blossfeld, H.-P., Klijzing, E., Mills, M. and Kurz, K. (eds) (2005) Globalization, uncertainty and youth in society, London: Routledge.

Breen, R. (2010) 'Educational expansion and social mobility in the 20th century', Social Forces, 89(2): 365-88. doi: 10.1353/sof.2010.0076

Breen, R. and Buchmann, M. $(\overline{2002})$ 'Institutional variation and the position of young people: A comparative perspective', ANNALS of the American Academy of Political and Social Science, 580(1): 288-305. doi: 10.1177/000271620258000112

Brzinsky-Fay, C. and Solga, H. (2016) 'Compressed, postponed, or disadvantaged? Schoolto-work-transition patterns and early occupational attainment in West Germany', Research in Social Stratification and Mobility, 46(Pt A): 21-36. doi: 10.1016/j.rssm.2016.01.004

Buchmann, M.C. and Kriesi, I. (2011) 'Transition to adulthood in Europe', Annual Review of Sociology, 37: 481-503. doi: 10.1146/annurev-soc-081309-150212

Bynner,J. (2001) 'British youth transitions in comparative perspective', Journal of Youth Studies, 4(1): 5-23. doi: 10.1080/13676260120028529

Bynner, J. and Parsons, S. (2002) 'Social exclusion and the transition from school to work: The case of young people not in education, employment, or training (NEET)', Journal of Vocational Behavior, 60(2): 289-309. doi: 10.1006/jvbe.2001.1868 
Crosnoe, R. and Smith, C. (2017) 'Structural advantages, personal capacities and young adult functioning during the Great Recession', in I. Schoon and J. Bynner (eds) Young people's development and the Great Recession: Uncertain transitions and precarious futures, Cambridge: Cambridge University Press, pp 129-53.

Danzinger, S. (2013) 'Evaluating the effects of the recession', ANNALS of the American Academy of Political and Social Science, 650(1): 6-24. doi:10.1177/0002716213500454

Dolado, J.J. (ed.) (2015) No country for young people? Youth labour market problems in Europe, London: CEPR Press.

Elder, G.H. (1999) Children of the Great Depression: Social change in life experience (25th anniversary edition), Boulder, CO:Westview Press (orig. published in 1974, University of Chicago Press).

Elder, G.H., Shanahan, M.J. and Jennings, J.A. (2015) 'Human development in time and place', in M.H. Bornstein and T. Leventhal (eds) Handbook of child psychology and developmental science, volume 4: Ecological settings and processes in developmental systems, Hoboken, NJ:Wiley, pp 6-54.

Emmenegger, P., Häusermann, S., Palier, B. and Seeleib-Kaiser, M. (eds) (2012) Age of dualization: The changing face of inequality in deindustrializing societies, Oxford: Oxford University Press.

Eurofound (2013) 'Young people and temporary employment in Europe'.Available at:www. eurofound.europa.eu/sites/default/files/ef_files/docs/erm/tn1304017s/tn1304017s.pdf.

Eurofound (2016) Exploring the diversity of NEETs, Dublin: European Foundation for the Improvement of Living and Working Conditions. Available at: www.eurofound. europa.eu/sites/default/files/ef_publication/field_ef_document/ef1602en.pdf.

Eurofound (2017) Long-term unemployed youth: Characteristics and policy responses, Dublin: European Foundation for the Improvement of Living and Working Conditions. Available at: www.eurofound.europa.eu/publications/report/2017/long-termunemployed-youth-characteristics-and-policy-responses.

European Commission (2016) EU Youth Report 2015. Luxembourg: Publications Office of the European Union.Available at: http://ec.europa.eu/assets/eac/youth/ library/reports/youth-report-2015_en.pdf.

Eurostat (2017a) 'Educational attainment statistics'.Available at: http://ec.europa.eu/ eurostat/statistics-explained/index.php/Educational_attainment_statistics.

Eurostat (2017b) 'Temporary employment in the EU'.Available at: https://ec.europa. eu/eurostat/web/products-eurostat-news/-/DDN-20170502-1.

Evans, K. and Heinz, W.R. (eds) (1994) Becoming adults in England and Germany, London: Anglo-German Foundation.

Ferragina, E. and Seeleib-Kaiser, M. (2011) 'Welfare regime debate: past, present, future', Policy and Politics, 39(4): 583-611. doi: 10.1332/030557311X603592

Furlong, A. (2010) 'Transitions from education to work: New perspectives from Europe and beyond', British Journal of Sociology of Education, 31(4): 515-18. doi: 10.1080/01425692.2010.484926

Furlong,A. and Cartmel, F. (2007) Young people and social change (2nd edn), Buckingham: Open University Press.

Giddens, A. (1991) Modernity and self-identity: Self and society in the late modern age, Cambridge: Polity Press.

Groh-Samberg, O. and Wise, R. (2017) 'Education and employment transitions in Germany before and after the financial crisis', in I. Schoon and J. Bynner (eds) 
Young people's development and the Great Recession: Uncertain transitions and precarious futures, Cambridge: Cambridge University Press, pp 177-207

Heckhausen, J. and Buchmann, M. (2018) 'A multi-disciplinary model of lifecourse canalization and agency', Advances in Life Course Research. doi: 10.1016/j. alcr.2018.09.002

Heinz, W.R. (2009) 'Structure and agency in transition research', Journal of Education and Work (Special issue: Continuity and change in 40 years of school to work transitions), 22(5): 391-404. doi: 10.1080/13639080903454027

Heinz,W.R. (ed.) (1999) From education to work: Cross-national perspectives, Cambridge: Cambridge University Press.

ILO (International Labour Organization) (2012) 'Global employment trends for youth 2012'. Available at: www.ilo.org/global/research/global-reports/youth/2012/ lang--en/index.htm.

ILO (International Labour Organization) (2017) Global employment trends for youth 2017: Paths to a better working future, Geneva: ILO. Available at: www.ilo.org/ wcmsp5/groups/public/---dgreports/---dcomm/---publ/documents/publication/ wcms_598669.pdf.

Liefbroer, A.C. and Billari, F.C. (2010) 'Bringing norms back in: A theoretical and empirical discussion of their importance for understanding demographic behaviour', Population Space and Place, 16(4): 287-305. doi: 10.1002/psp.552

Lyons-Amos, M. and Schoon, I. (2017) 'Employment and family transitions in the UK:Trends before and after the Great Recession', In I. Schoon and J. Bynner (eds) Young people's development and the Great Recession: Uncertain transitions and precarious futures, Cambridge: Cambridge University Press, pp 297-317.

Maguire, S. (2015) 'NEET, unemployed, inactive or unknown — why does it matter?' Educational Research, 57(2): 121-32. doi: 10.1080/00131881.2015.1030850

Mortimer, J.T., Kirkpatrick Johnson, M. and Mont'Alvao, A. (2017) 'Economic recession and youth achievement orientations', in I. Schoon and J. Bynner (eds) Young people's development and the Great Recession: Uncertain transitions and precarious futures, Cambridge: Cambridge University Press, pp 321-47.

Müller, W. and Gangl, M. (eds) (2003) Transitions from education to work in Europe. The integration of youth into EU labour markets. Oxford: Oxford University Press.

Neugarten, D. (1996) The meanings of age: Selected papers of Bernice Neugarten, Chicago: University of Chicago Press.

OECD (Organisation for Economic Co-operation and Development) (2010) Off to a good start? Jobs or youth. Paris: OECD Publishing. Available at: www.oecd.org/ els/offtoagoodstartjobsforyouth.htm.

OECD (Organisation for Economic Co-operation and Development) (2017) Education at a Glance: OECD Indicators. Paris: OECD Publishing. Available at: www. oecd-ilibrary.org/education/education-at-a-glance-2017_eag-2017-en.

OECD (Organisation for Economic Co-operation and Development) (2018a) 'Enrolment rate' (indicator).Available at: https://data.oecd.org/eduatt/enrolmentrate.htm.

OECD (Organisation for Economic Co-operation and Development) (2018b), Youth not in employment, education or training (NEET) (indicator). doi: 10.1787/72d1033a-en (Accessed 25 January 2019)

OECD (Organisation for Economic Co-operation and Development) (2019), Youth unemployment rate (indicator). doi: 10.1787/c3634df7-en (Accessed 25 January 2019) 
Pfeffer, F.T. and Hertel, F.R. (2015) 'How has educational expansion shaped social mobility trends in the United States?' Social Forces, 94(1): 143-80. doi: 10.1093/ sf/sov045

Prassl, J. (2018) Humans as a service: The promise and perils of work in the gig economy, Oxford: Oxford University Press.

Raffe, D. (2008) 'The concept of transition system', Journal of Education and Work, 21(4): 277-96. doi: 10.1080/13639080802360952

Raffe, D. (2014) 'Explaining national differences in education-work transitions', European Societies, 16(2): 175-93. doi: 10.1080/14616696.2013.821619

Rueda, D. (2014) 'Dualization, crisis and the welfare state', Socio-Economic Review, 12(2): 381-407. doi: 10.1093/ser/mwu015

Schoon, I. (2007) 'Adaptations to changing times: Agency in context', International Journal of Psychology, 42(2): 94-101. doi: 10.1080/00207590600991252

Schoon, I. (2015) 'Gender and the transition to adulthood:A diverse pathways view', in R. Scott and S. Kosslyn (eds) Emerging trends in the social and behavioral sciences: $A n$ interdisciplinary, searchable, and linkable resource, John Wiley \& Sons, Inc. Available at: https://onlinelibrary.wiley.com/doi/book/10.1002/9781118900772.

Schoon, I. and Bynner,J. (eds) (2017) Young people's development and the Great Recession: Uncertain transitions and precarious futures, Cambridge: Cambridge University Press. doi: $10.1017 / 9781316779507$

Schoon, I. and Lyons-Amos, M. (2016) 'Diverse pathways in becoming an adult:The role of structure, agency and context', Research in Social Stratification and Mobility, 46(Pt A): 11-20. doi: 10.1016/j.rssm.2016.02.008

Schoon, I. and Silbereisen, K.R. (eds) (2009) Transitions from school to work: Gglobalisation, individualisation, and patterns of diversity, New York: Cambridge University Press.

Schumpeter,J.A. (1975 [1942]) Capitalism, socialism and democracy, New York: Harper.

Settersten, R.A. Jr (2007) 'Passages to adulthood: Linking demographic change and human development', European Journal of Population, 23(3/4):251-72. doi: 10.1007/ s10680-007-9132-8

Settersten, R.A., Ottusch, T.M. and Schneider, B. (2015) 'Becoming adult: Meanings of markers to adulthood', in R.A. Scott and S.M. Kosslyn (eds), Emerging trends in the social and behavioral sciences: An interdisciplinary, searchable, and linkable resource, John Wiley \& Sons, Inc. Available at: https://onlinelibrary.wiley.com/doi/ book/10.1002/9781118900772.

Shanahan, M.J. (2000) 'Pathways to adulthood in changing societies:Variability and mechanisms in life course perspective', Annual Review of Sociology, 26: 667-92. doi: 10.1146/annurev.soc.26.1.667

Shanahan, M.J., Mortimer, J.T. and Kirkpatrick-Johnson, M. (eds) (2016) Handbook of the life course, volume II, New York: Springer.

Sironi, M. (2018) 'Economic conditions of young adults before and after the Great Recession', Journal of Family and Economic Issues, 39(1): 103-16. doi: 10.1007/ s10834-017-9554-3

Standing, G. (2011) The precariat: The new dangerous class, London: Bloomsbury.

Walther, A. (2006) 'Regimes of youth transitions: Choice, flexibility and security in young people's experiences across different European contexts', Young, 14(2): 119-39. doi: 10.1177/1103308806062737 